\title{
Middle Years of Marriage: Love and Marital Satisfaction Among Wives
}

\author{
Firza Ersalina Prasetyo, Sri Wahyuningsih, and Nurlita Endah Karunia \\ Faculty of Psychology \\ Universitas Surabaya
}

\begin{abstract}
In the middle years of marriage, marital satisfaction tends to decline, particularly among wives because of their caregiving roles for children and parents (transgenerational squeeze), and because their husbands focus more on their work. This may weaken love despite that love can provide happiness and lead to marital satisfaction. This study examined the relationships between love and marital satisfaction and determined which components of love that had the highest correlation with marital satisfaction. Data collected using questionnaires. Results showed that love had a positive relationship with wives' marital satisfaction in the middle years of marriage $(p<.001)$. The components of love having significant relationships with marital satisfaction from the highest to the lowest correlation were intimacy, commitment, and passion.
\end{abstract}

Keywords: marital satisfaction, love, components of love, the middle years of marriage, wife.

Pada usia pertengahan perkawinan, kepuasan perkawinan biasanya akan menurun, terutama pada istri karena peran pengasuhan untuk anak dan orang tua (transgenerational squeeze), serta suami berfokus pada pekerjaan. Hal tersebut membuat turunnya cinta pada perkawinan, padahal cinta dapat memberikan kebahagiaan dan mengarah pada kepuasan perkawinan. Penelitian ini bertujuan melihat hubungan antara cinta dengan kepuasan perkawinan dan komponen cinta yang paling tinggi korelasinya dengan kepuasan perkawinan di periode tersebut. Pengambilan data mengunakan angket. Hasil menunjukkan cinta memiliki hubungan positif dengan kepuasan perkawinan pada istri di periode pertengahan perkawinan $(p<.001)$. Komponen cinta dari yang paling tinggi ke paling rendah nilai korelasinya dengan kepuasan perkawinan adalah intimacy, commitment, dan passion.

Kata kunci: kepuasan perkawinan, cinta, komponen cinta, periode pertengahan perkawinan, istri.

Marital satisfaction reflects an evaluation towards parenting and communication issues and happiness experienced by husbands and wives in a marital relationship (Fowers \& Olson, 1993). Marital satisfaction includes 10 aspects; that is, personality issues, communication, conflict resolution, financial management, leisure activities, sexual relationship, children and parenting, family and friends, equalitarian roles, and religious orientation (Fowers \& Olson, 1989). Khan dan Aftab (2013) explains that marital satisfaction is a key factor to the successful of marriage. Marital satisfaction arises from happiness to love each other (Oprisan \& Cristea, 2012). Love is considered impor-

Correspondence concerning this article should be addressed to Firza Ersalina Prasetyo, Faculty of Psychology Universitas Surabaya, jalan Raya Kalirungkut Surabaya 60293 E-mail: 5120206.firzaersalinaprasetyo@gmail.com tant in a marital relationship because three components of love interact and therefore, minimize conflict and lead to happiness and marital satisfaction (Sternberg in Muchtar, 2004; Sadiq, 2014). Previous survey indicates that 18 out of $20(90 \%)$ wives in Surabaya agreed that love was a key factor in a marital relationship.

Love, according to Sternberg (1986), can be categorized into three components; that is, passion, intimacy, and commitment that interact to generate different types of love and express in acts of loving another person. Passion includes sexual drives and physical attraction, whereas intimacy is a feeling of closeness, attachment, and connectedness (Sternberg, 1986). Commitment can be divided into short-term and longterm commitment where short term commitment relates to a decision to love a person and long-term 
commitment relates to the acts of maintaining love (Sternberg, 1997). If love in particular the three components of love are at the same high level, it is most likely that high marital satisfaction will be attained and maintained (Carandang \& Guda, 2015).

This study would examine the relationships between love, including the three components of love, and marital satisfaction in the middle years of marriage. Marital satisfaction shows " $U$ " curve during the three period of marriage (Papalia, Sterns, Feldman, \& Camp, 2002). The highest level of marital satisfaction is in the early and later years. In the middle years of marriage, there is a honeymoon phase that involves both physical and emotional attachment (Hatfield, Pillemer, O'Brien, \& Le, 2008; Kenrick, Linsenmeier, Li, \& Bailey in Schmitt, Kliegel, \& Shapiro, 2007). Physical and emotional attachment indicates a high level of passion and intimacy (Sternberg, 1997). In the later years of marriage, husbands and wives are free from the roles of caregiving and workers, and therefore, they spend more time together and feel closeness as a couple; this leads to a higher level of intimacy (Papalia, Sterns, Feldman, \& Camp, 2007).

The lowest level of marital satisfaction is in the middle years of marriage. The middle years of marriage is the length of marriage between 10 to 30 years (Ruben in Muchtar, 2004) indicated by a decrease in marital satisfaction, particularly among women because of their caregiving roles (Papalia, Sterns, Feldman, \& Camp, 2007). The role of caregiving in the middle years of marriage taken by wives in the middle period of their life requires them to only care for younger generation (their child), but also for older generation (their parents); this is called as transgenerational squeeze (Bjorklund, \& Bee, 2008). While wives are busy with their caregiving role, husbands tend to focus on their career, and thus, husbands and wives begin to lose their sexual drive, resulting a further decrease in intimate relationships particularly when there is no discussion about this problem (Papalia, Sterns, Feldman, \& Camp, 2007). A lack of intimate communication and declined sexual drive lead to a decrease in passion and intimacy (Sternberg as cited in $\mathrm{Li} \& \mathrm{Yu}, 2009$ ).

Previous studies have shown that there was a relationship between love and marital satisfaction of husband and wives (Carandang \& Guda, 2015; Hoesni, Subhi, Alavi, \& Wan Azreena, 2013; Tung, 2007; Muchtar, 2004). However, the studies differ in the component of love that has the highest correlation with marital satisfaction. Several studies revealed intimacy (Carandang \& Guda, 2015), and then followed by passion (Hoesni, Subhi, Alavi, \& Wan Azreena, 2013) as the compo- nents of love having the highest correlation with marital satisfaction. Other studies showed that only intimacy and passion had significant relationships with marital satisfaction (Muchtar, 2004). The most probable explanation is that these studies were conducted in three different cities; that is, a city in the Philipines, Malaysia, and Jakarta Furthermore, the sample used in the studies are different, one study involves both husbands and wives, the other study involves only husbands. Sternberg (in Nihayah, Adriani, \& Wahyuni, 2012; Jackson, Chen, Guo, \& Gao, 2006) explains that the components of love influence marital satisfaction at different levels because love is considered as a story written by each person in accordance to what he or she expects from a relationship; and this will influence his or her responses to the relationship. This present study aimed to examine the relationships between love and marital satisfaction merely among wives in the middle years of marriage.

\section{Method}

This study used a quantitative survey method with a cross-sectional design. Participants were wives who were in the middle years of marriage; that is, having the length of marriage between 10 to 30 years, they had at least one child and their educational background was at least high school or equivalent. This study was conducted at the region of $\mathrm{M}$, Menur Pumpungan, district of Sukolilo, Surabaya. Sampling techniques used were snowball and accidental sampling. Snowball sampling was used to recruit an eligible participant as a key informant who would then refer to another eligible participant, while accidental sampling was used to recruit participants encountered by chance and met the eligibility criteria (Neuman, 1997).

Data collection was conducted using a series of questionnaire with open-ended and close-ended questions. The questionnaire with open-ended questions enquired problems experienced by wives in the middle years of marriage. The questionnaire with closedended questions was a 4-point Likert scale (very true of me, true of me, untrue of me, and very untrue of me) related to love and marital satisfaction. The options for the response were limited to four by eliminating the not sure or neutral to prevent participants from choosing the middle response (central tendency bias). The scales contain only favourable items. Love questionnaire was based on Sternberg's Triangular Theory of Love Scale (TTLS) adapted by Muchtar (2004). It 
Table 1

Demographic Characteristic of Participants Reported in the Most Frequent Number

\begin{tabular}{llcc}
\hline & \multirow{2}{*}{ Demographic Characteristics } & \multicolumn{2}{c}{ Frequency } \\
\cline { 3 - 4 } & & $n$ & $\%$ \\
\hline Age & 35-39 years old & 19 & 46.3 \\
Length of marriage & 10-15 years old & 32 & 78 \\
Age at marriage & 20-25 years old & 29 & 70.7 \\
Education level & Senior high school (husband and wife) & 22 & 53.7 \\
Occupation & Unemployed (wife) & 24 & 58.5 \\
& Private employee (husband) & 22 & 53.7 \\
Income & No income (wife) & 23 & 56.1 \\
& 2-3 million (husband) & 19 & 46.3 \\
Number of children & 2 children & 21 & 51.2 \\
Child age & 6-11 years old (first born) & 18 & 43.9 \\
& 6-11 years old (second born) & 19 & 46.3 \\
Living status & 2-3 years old (third born) & 3 & 7.3 \\
& With a husband and children & 30 & 73.2 \\
\hline
\end{tabular}

consists of 21 items $(\alpha=.955 ; r=.483-.837)$. TTLS was adapted by Muchtar with the e-mail permission from Sternberg. Muchtar translated and trialled the questionnaire prior to this present study. Marital satisfaction questionnaire was adapted from ENRICH Marital Satisfaction Scale (EMS Scale), a unidimensional questionnaire based on Fower's and Olson's theory of marital satisfaction $(1989 ; 1993)$. The questionnaire consists of 20 items $(\alpha=.938 ; r$ $=.319-.655)$. All items of the EMS Scale were translated into Indonesian and we added one or two items based on definition of each aspect of marital satisfaction by Fower and Olson. The reason for adding items was to provide more specific questions. For example, an item was added to measure satisfaction with parents-in-law, brothers or sisters, and friends. Data collected would be analysed with an SPSS program for Windows version 16.0.

\section{Results}

In this present study, data were obtained from 41 participants. Data were divided into two parts. The first part was demographic data of participants. The second was data from the two questionnaires, TTLS and EMS Scale that were used to categorize the scale scores (very high, high, low, and very low) and to generate correlational analyses. Demographic data include participants' age, length of marriage, age at marriage, education level, occupational status, income, number of children, child age, and living status.

Table 1 shows that most wives were at the age of $35-39$ years old $(46.3 \%)$ with the length of marriage between 10 and 15 years (78\%), and married at the age of 20-25 years old (70.7\%). The education qualification of most wives was senior high school or equivalent, the same case occurred with most husbands $(53.7 \%)$.

Wives were generally unemployed (58.5\%) and had no income $(56.1 \%)$, whereas most husbands worked as private employees $(53.7 \%)$ and had income between two to three million Indonesian Rupiah (46.3\%). Additionally, most wives had two children (51.2\%) at school age (6-11 years old), and lived with their husbands and children $(73.2 \%)$.

Table 2 reveals data from open-ended questions showing problems experienced by wives in the middle

Table 2

List of Problems Experienced by Wives in the Middle Years of Marriage Reported in the Most Frequent Response

\begin{tabular}{|c|c|c|c|c|c|}
\hline \multirow[t]{2}{*}{ Problems } & \multicolumn{2}{|c|}{$\begin{array}{c}\text { Number of } \\
\text { responses based on } \\
\text { the total number of } \\
\text { participants }\end{array}$} & \multirow[t]{2}{*}{ Reasons } & \multicolumn{2}{|c|}{$\begin{array}{l}\text { Number of } \\
\text { responses based on } \\
\text { the total number of } \\
\text { participants }\end{array}$} \\
\hline & $N$ & $\%$ & & $N$ & $\%$ \\
\hline Raising children & 12 & 29.3 & Handed to wives & 5 & 12.2 \\
\hline Communication & 9 & 22.0 & Husband was busy with work & 3 & 7.3 \\
\hline Private time with husbands & 4 & 9.8 & Husband was busy with work & 3 & 7.3 \\
\hline
\end{tabular}


Table 3

Types of Support from Parents-in-Law or Parents

\begin{tabular}{lcc}
\hline \multirow{2}{*}{ Problems } & \multicolumn{2}{c}{$\begin{array}{c}\text { Number of response based on the } \\
\text { total number of participants }\end{array}$} \\
\cline { 2 - 3 } & $N$ & $\%$ \\
\hline Financial & 6 & 50.0 \\
Household work & 6 & 50.0 \\
\hline
\end{tabular}

Table 4

Category of Scores Reported in the Most Frequent Number

\begin{tabular}{llll}
\hline \multirow{2}{*}{ Variables } & \multicolumn{2}{c}{ Category } & \multicolumn{2}{c}{ Frequency } \\
\cline { 3 - 4 } & & $n$ & $\%$ \\
\hline Love & High $(69.75-90.44)$ & 26 & 63.4 \\
Intimacy & High $(23.47-31.22)$ & 23 & 56.1 \\
Passion & High $(21.64-29.52)$ & 24 & 58.5 \\
Commitment & High $(24.65-31.18)$ & 24 & 58.5 \\
Marital & High $(63.83-82.23)$ & 25 & 61.0 \\
satisfaction & & \\
\hline Note. +/-2 standard of deviation using visual binning.
\end{tabular}

Table 5

Correlation Between Love and its

Three Components and Marital Satisfaction

\begin{tabular}{ccc}
\hline Variable & $r$ & $p$ \\
\hline Love & 0.845 & $0.000^{*}$ \\
Intimacy & 0.848 & $0.000^{*}$ \\
Passion & 0.649 & $0.000^{*}$ \\
Commitment & 0.752 & $0.000^{*}$ \\
\hline Note. Spearman correlation $\left({ }^{*} p<.001\right)$. &
\end{tabular}

years of marriage. It showed that $29.3 \%$ of wives had an issue of raising children, $22.0 \%$ reported communication problems, and $9.8 \%$ had an issue of private time with husbands. The reasons for these three problems were also gathered. In raising children, the most frequent of reasons were feeling of burden because the role of raising children was handed to wives (12.2\%). Both problems with communication and private time with husbands occurred because husbands were busy with their work (7.3\%). Table 3 shows types of support provided to wives by parents or parents-in-law. The supports were financial support (50.0\%) and help with household work $(50.0 \%)$.

Table 4 shows that love and the three components of love and marital satisfaction were all categorised at high levels. From Table 5, it can be seen that love and its three components had positive and significant relationships with wives' marital satisfaction in the middle years of marriage $(p<.001)$. Additionally, the correlations between love, passion, intimacy and commitment and marital satisfaction were found high $(r>.7)$.

\section{Discussion}

The results indicate significant relationships between love and its three components (intimacy, passion, commitment) and marital satisfaction among wives in the middle years of marriage (Table 5). This is consistent with the result of previous studies showing the relationship between love and marital satisfaction (Muchtar, 2004; Carandang \& Guda, 2015; Hoesni, Subhi, Alavi, \& Wan Azreena, 2013; Tung, 2007). The relationship between love and marital satisfaction was also found positive indicating that the higher level of love was followed by the higher level of marital satisfaction. Table 5 shows that love and its three components had high correlations with marital satisfaction $(r>.5)$. The component of love with the highest correlation was intimacy $(r=.848)$, followed by commitment $(r=.752)$, and passion $(r=.649$; Table 5). This is consistent with a statement that the interaction of the three components of love could minimize conflicts and this leads to happiness and marital satisfaction (Sternberg in Muchtar, 2004; Sadiq, 2014).

Marital satisfaction in the middle years of marriage generally decreases because of wives' role in caregiving (Papalia, Sterns, Feldman, \& Camp, 2007) to not only younger generation (children) but also older generation (parents); this is called as transgenerational squeeze (Bjorklund \& Bee, 2008). While wives are busy with their caregiving roles, husbands are busy with their career. However, this study has provided evidence that love at a higher level relates to a high level of marital satisfaction in the middle years of marriage (Table 4), this relationships was positive and significant (Table 5). High marital satisfaction indicates that wives in the middle years of marriage are satisfied with their caregiving roles and relationships with their husbands. This is supported by a lower number of parent conflicts, such as in raising children $(29.3 \%)$ and feeling of burden because of caregiving roles (12.2\%; Table 2). Additionally, caregiving role to older generation (transgenerational squeeze) did not seem to take a great deal of wives' time or energy because most parents had provided financial support and involved in household works (50\%; Table 3). The lower level of conflict reported by wives in the middle years of marriage was more related to busy husbands, wives did not seem to have problems with communication (78\%) and private time with their husbands (90.2\%; Table 2).

\section{Limitations}

This study did not collect data of love and its three 
components (intimacy, passion, and commitment) using open-ended questions, thus we could not provide exhaustive explanation regarding the relationships between love and its three components, and marital satisfaction among wives in the middle years old marriage. Data using open-ended questions might provide a more objective account regarding the relationship between love and marital satisfaction, and therefore, they could provide detailed explanation and describe the real condition of participants. Another limitation is related to wording in instruction and items of questionnaire; the expression should be adjusted according to participants' characteristics to ensure their understanding towards the questions. This issue arises because we have not trialled the translated questionnaire and therefore, did not receive feedback regarding the word choice.

The number of participants in this study was only 41 wives which is less than the total population of wives in Indonesia that met the eligibility criteria for this study. Furthermore, participants might not represent the population because of non-random sampling technique used in this study.

\section{Conclusion and Recommendation}

The result of this study showed that there was a positive and significant relationship between love and marital satisfaction among wives in the middle years of marriage. Positive and significant relationships were also found between each component of love and marital satisfaction. The coefficients of correlation between the three components of love and marital satisfaction from the highest to the lowest were as follows: intimacy, commitment, and passion.

Love and the three components of love were found having an important and significant role in marital satisfaction of wives in the middle years of marriage. Therefore, they should be given more attention and expressed more frequently in a married life. This is important particularly for husbands to meet their wives' needs for affection which could be expressed through the three components of love. For example, husbands can spend more private time with their wives, express their love verbally and physically (kissing, hugging, and so on).

Further research could involve not only wives but also husbands as participants in order to obtain a broader view of marital satisfaction. Additionally, future study could extend their findings by including participants not only in the middle years of marriage, but also in the early and later years of marriage in order to examine clearly the fluctuation love and the three components of love (intimacy, passion, commitment), as well as marital satisfaction.

\section{References}

Bjorklund, B. R., \& Bee, H. L. (2008). The journey of adulthood (6th ed.). New York: Pearson Education.

Carandang, M. N. S., \& Guda, I. V. P. (2015). Indicators of marital satisfaction of Batangueño couples: Components of love and the other external factors in marriage. International Journal of Information and Education Technology, 5(1), 60-67.

Fowers, B. J., \& Olson, D. H. (1989). ENRICH marital inventory: A discriminant validity and crossvalidity assessment. Journal of Marital and Family Therapy, 15(1), 65-79.

Fowers, B. J., \& Olson, D. H. (1993). ENRICH marital satisfaction scale: A brief research and clinical tool. Journal of Family Psychology, 7(2), 176-185.

Hatfield, E., Pillemer, J. P., O’Brien, M. U., \& Le, Y. L. (2008). The endurance of love: Passionate and companionate love in newlywed and long-term marriages. Interpersona, 2(1), 35-64.

Hoesni, S. M., Subhi, N., Alavi, K., \& Wan Azreena, W. J. (2013). Exploring love and marital satisfaction among married Malay males. Pertanika Journals of Social Sciences and Humanities, 21, 59-68.

Jackson, T., Chen, H., Guo, C., \& Gao, X. (2006). Stories we love by conceptions of love among couples from the people's Republic of China and The United States. Journal of Cross-Cultural Psychology, 37(4), 446-464.

Khan, F., \& Aftab, S. (2013). Marital satisfaction and perceived social support as vulnerability factors to depression. American International Journal of Social Science, 2(5), 99-107.

Li, Z., \& Yu, F. (2009). Inquiring love of this world: An implicit love theory of Chinese university students. Asian Culture and History, 1(1), 14-24.

Muchtar, D. Y. (2004). Analisis hubungan cinta dengan kepuasan pernikahan. Retrieved from http://reposi tory.uinjkt.ac.id/dspace/bitstream/123456789/9467/ 1/DESI\%20YUSTARI\%20MUCHTAR-PSI.pdf

Neuman, W. L. (1997). Social research methods: Qualitative and quantitative approaches (3rd ed.). Boston: Allyn \& Bacon.

Nihayah, Z., Adriani, Y., \& Wahyuni, Z. I. (2012). Peran religiusitas dan faktor-faktor psikologis terhadap kepuasan perkawinan. Retrieved from http:// eprints.uinsby.ac.id/265/1/Buku\%202\%20Fix_425. 
pdf

Oprisan, E., \& Cristea, D. (2011). A few variables of influence in the concept of marital satisfaction. Procedia - Social and Behavioral Sciences, 33, 468 $-472$.

Papalia, D. E., Sterns, H. L., Feldman, R. D., \& Camp, C. J. (2007). Adult development and aging (3rd ed.). New York: McGraw-Hill.

Sadiq, R. (2014). Affection expression and consensus in marital relation a determinants of life satisfaction among wives. Middle-East Journal of Scientific Research, 21(5), 839-843.

Schmitt, M., Kliegel, M., \& Shapiro, A. (2007). Marital interaction in middle and old age: A predictor of marital satisfaction? The International Journal of Aging and Human Development, 65(4), 283-300.

Tung, T. P. (2007). Romantic relationship: Love styles, triangular love, and relationship satisfaction. Retrieved from http://lbms03.cityu.edu.hk/oaps/ss2 007-4708-tpt530.pdf 